\title{
Foetal and maternal rates of urea production and disposal in well-nourished and undernourished sheep
}

\author{
BY J. C. HODGSON, D. J. MELLOR AND A. C. FIELD \\ Moredun Research Institute, 408 Gilmerton Road, Edinburgh EH17 7JH, Scotland
}

(Received 25 August 1981- Accepted 8 January 1982)

1. Five monotocous and two ditocous Scottish Blackface ewes with indwelling catheters in an umbilical artery and vein of one foetus only and in both maternal jugular veins were used.

2. Experiments were conducted over a period of $2 \mathrm{~d}$ when $\left[{ }^{14} \mathrm{C}\right]$ urea was infused intravenously over $9 \mathrm{~h}$ into either the mother or foetus, separate days being used for each infusion. Two series of experiments were completed, one in well-nourished and the other in undernourished sheep at 125-141 and 138-143 d of gestation respectively.

3. Plasma urea specific radioactivities of the mother and infused foetus at plateau were used to determine the urea flux-rates within and between mother and foetus. The mean rate of foetal urea production $\left(F_{\text {to }}\right)$ was 1.45 and $1.63 \mathrm{mg} / \mathrm{min}$ per $\mathrm{kg}$ foetus in well-nourished and undernourished ewes respectively. The corresponding rates of maternal urea production $\left(F_{\mathrm{mo}}\right)$ were 0.49 and $0.37 \mathrm{mg} / \mathrm{min}$ per $\mathrm{kg}$ live weight respectively and there was a close correlation between the rate of maternal urea disposal $\left(F_{\mathrm{om}}\right)$ and the dietary nitrogen intake.

4. The values of $F_{\mathrm{fo}}$ were used to calculate the maximum potential for foetal gluconeogenesis from deaminated amino acids. These calculations were compared with published information on the over-all rates of foetal gluconeogenesis in well-nourished ewes.

5. The foetal entry rate of urea expressed on a body-weight basis was high, approximately 8-5 times that of the mother, but it was a threefold overestimate of $F_{\mathrm{fo}}$. The maternal entry rate was 1.3 times $F_{\text {mo }}$ and the significance of this in relation to assessing differences in urea entry rates in pregnant and non-pregnant sheep is discussed.

Hodgson et al. $(1980,1981)$ measured the rates of glucose production and utilization in pregnant and foetal sheep and observed that $0.31-0.44$ of the foetal rate of glucose use was supplied by foetal gluconeogenesis. It was suggested that the carbon required for this process came predominantly from foetal amino acids (Hodgson et al. 1980). However, it is difficult to accurately determine the rate of gluconeogenesis from radioactively-labelled amino acids due to problems such as cross-over of label (Lindsay, 1978) and low levels of foetal glucose labelling during radioactive infusions of individual acids (e.g. Prior \& Christenson, 1977). Therefore in the present work the over-all rate of foetal amino acid degradation was assessed by measuring the foetal rate of urea production, and this was used to estimate the maximum potential contribution of amino acid-C to foetal gluconeogenesis. It was found that in well-nourished sheep the mean foetal rate of urea production was $1.45 \mathrm{mg} / \mathrm{min}$ per $\mathrm{kg}$ foetus, indicating that amino acids could account for a maximum of 0.9 and 0.5 of the total rate of foetal gluconeogenesis observed in monotocous (Hodgson et al. 1980) and ditocous (Hodgson et al. 1981) sheep respectively. In addition, the maternal-foetal urea kinetics were studied in undernourished sheep, providing a value for the mean rate of foetal urea production of $1.63 \mathrm{mg} / \mathrm{min}$ per $\mathrm{kg}$ foetus.

\section{MATERIALS AND METHODS}

\section{Animals and management}

Five monotocous and two ditocous Scottish Blackface ewes weighing 45-70 kg were housed, trained and maintained and had maternal and foetal catheters inserted as described previously (Hodgson \& Mellor, 1977; Hodgson et al. 1980). Only one foetus was catheterized in each twin-bearing ewe. All animals were offered ruminant diet A, a complete diet of standardized composition (Wainman et al. 1970), throughout. 
Experimental series 1. Three sheep (one monotocous, two ditocous) were used. Between 125 and $141 \mathrm{~d}$ of gestation their average daily intake of the diet, offered in equal portions at two-hourly intervals, was $25 \cdot 9 \pm 0.5 \mathrm{~g} / \mathrm{kg}$ ewe live weight.

Experimental series 2. Four monotocous sheep were used. Their average dietary intake, provided in equal portions at hourly intervals, was initially $26.7 \pm 0.8 \mathrm{~g} / \mathrm{kg}$ ewe live weight per $\mathrm{d}$ but at $126-130 \mathrm{~d}$ of gestation it was reduced abruptly to, and thereafter maintained at, $11 \cdot 8 \pm 1 \cdot 2 \mathrm{~g} / \mathrm{kg}$ ewe live weight per $\mathrm{d}$.

\section{Radioactive tracer infusions}

Infusates were sterile sodium chloride solutions $(0 \cdot 15 \mathrm{M})$ containing $\left[{ }^{14} \mathrm{C}\right]$ urea (Amersham International Limited, Amersham) and carrier urea (0.42 mM). The mother was infused at a rate of $4 \mathrm{ml} / \mathrm{h}$ via a jugular vein for $9 \mathrm{~h}$ on day 1 , and the foetus similarly infused $15 \mathrm{~h}$ later via an umbilical vessel on day 2 (for the route of each foetal infusion, see Table 2), using a syringe pump (model SP15/A; Scientifica and Cook Electronics, London W3 8AU). It was assumed that over the experimental period of $33 \mathrm{~h}$ there would be little change in the urea kinetics of either mother or foetus (for comments relating to glucose kinetics, see Hodgson \& Mellor (1977)).

Experimental series 1. Five experiments were conducted between days 125 and 141 of gestation when a primed infusion of $\left[{ }^{14} \mathrm{C}\right]$ urea was given at a rate $0.44 \pm 0.01 \mu \mathrm{Ci} / \mathrm{min}$, using a dose to infusion rate ratio $(\mu \mathrm{Ci}: \mu \mathrm{Ci} / \mathrm{min})$ of $100: 1$. Experiments were repeated at $5 \mathrm{~d}$ intervals twice in sheep T849. The infused foetuses in ditocous sheep were identified after killing the ewe at $132 \mathrm{~d}$ (T681) or $141 \mathrm{~d}$ (T849) of gestation.

Experimental series 2. Four experiments were conducted between days 138 and 143 of gestation when $\left[{ }^{14} \mathrm{C}\right]$ urea was infused at a rate of $0.32 \pm 0.01 \mu \mathrm{Ci} / \mathrm{min}$ with no priming dose. Previously, at 124-129 and 131-136 d of gestation, the kinetics of glucose metabolism had been examined according to Hodgson et al. (1980); the results of these experiments are to be reported elsewhere.

Residual radioactivity. The plateau specific radioactivities were corrected for any residual radioactivity present in plasma immediately before a repeat infusion, which on day 2 of an experiment was $0.08-0.12$ and $0.04-0.08$ of the day 1 plateau for foetal and maternal samples respectively, and 0.01 or less of the preceeding plateau immediately before a repeat experiment.

\section{Sampling and analyses}

Blood samples were obtained and processed as described previously (Hodgson et al. 1980). Plasma urea specific radioactivities were determined after deproteinization (Somogyi, 1945) of the plasma (cf. Nolan \& Leng, 1970). The supernatant fraction (1 ml) was added to 10 $\mathrm{ml}$ NE250 scintillant (Nuclear Enterprises, Edinburgh) and counted in an automatic liquid-scintillation spectrometer (NE8312; Nuclear Enterprises) using low-potassium-glass scintillation vials (Poulten, Selfe and Lee Ltd., Wickford, Essex). The urea concentrations in plasma and deproteinized plasma were measured by the method of Fawcett \& Scott (1960) using reagents supplied by BCL (catalogue No. 124788; The Boehringer Corporation (London) Ltd, Lewes, East Sussex). Plasma glucose concentrations were determined by the method of Trinder (1969).

\section{Mathematical analysis}

The calculations were simplified by the observation that the plateau specific radioactivities of maternal plasma urea were, for a given infusion rate, the same whether the mother or foetus was infused (see Table 2). This indicated that there was no output from the foetal urea pool other than via the mother and therefore that the rate of foetal urea production 
(a)

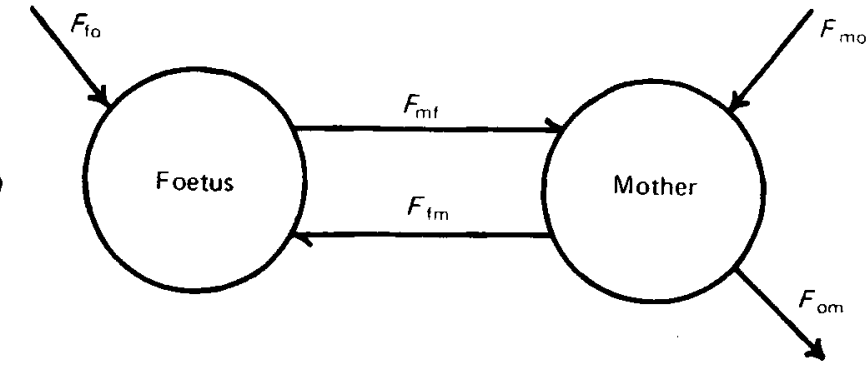

(b)

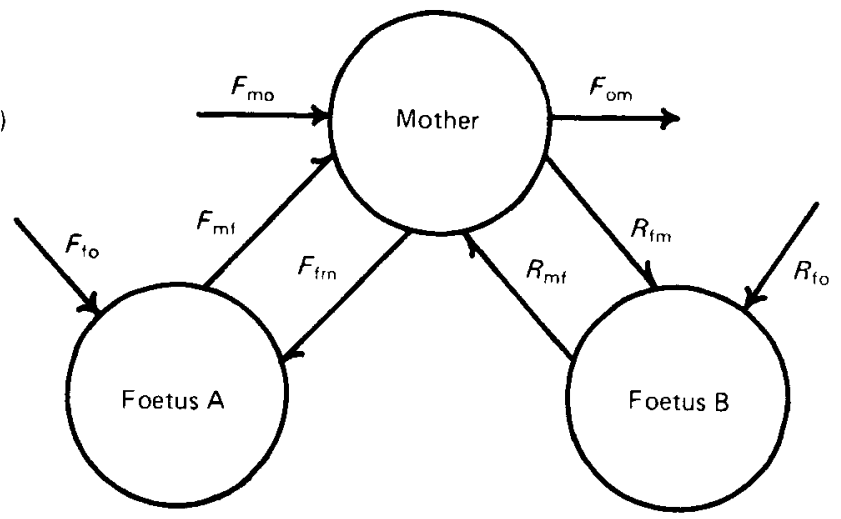

Fig. 1. Models of the maternal-foetal urea system in monotocous ( $a$ ) and ditocous $(b)$ ewes. m, Maternal urea pool; $f$, the foetal urea pool. The method of notation is taken from Shipley \& Clark (1972). $F_{\text {mo, }}$, urea production during the deamination of amino acids and the detoxification of absorbed ammonia in the mother; $F_{\mathrm{om}}$, urea lost from the maternal plasma via the kidneys or to the alimentary tract; $F_{\mathrm{mt}}-F_{\mathrm{fm}}$, net transfer of urea from the infused foetus to the mother ${ }^{*} F_{\mathrm{fo}}$, urea production during the deamination of amino acids in the infused foetus.*

* Similar considerations apply to foetus $\mathrm{B}$, substituting $R$ for $F$.

was equal to the net rate of transfer of urea from foetus to mother. Thus partially-restricted two- or three-pool models were chosen to represent the maternal-foetal urea system of monotocous and ditocous ewes respectively (Fig. 1). The parameters of the two-pool model were calculated as described previously for glucose (Hodgson et al. 1980). The results from ditocous ewes were similarly analysed to provide rates of production and disposal in the infused foetus (foetus A). The equivalent rates in the uninfused foetus (foetus B) were then estimated on the basis of the relative twin foetal weights (cf. Hodgson et al. 1981). The true rate of maternal urea production $\left(F_{\mathrm{mo}}\right)$ was obtained by subtracting the estimated rate of urea production in foetus B $\left(R_{\mathrm{fo}}\right)$ from that in the mother determined from the two-pool model $\left(F_{\text {mo }}^{*}\right)$. That is,

$$
F_{\mathrm{mo}}=F_{\mathrm{mo}}^{*}-R_{\mathrm{fo}} .
$$

\section{RESULTS}

The mean concentrations of urea in foetal and maternal plasma during each experiment are given in Table 1. The within-day variation in concentration was small, with the mean \pm SEM coefficient of variation being $5 \cdot 7 \pm 0.5 \%(n 33)$ for all foetal and maternal samples. In the second experimental series between-day variation was also small (Table 1) and a steady-state with respect to urea kinetics was assumed. However, in experimental series 1 there was a tendency for plasma urea concentrations to be higher on the second than on the first day of an experiment. Although this made the assumption of steady-state 


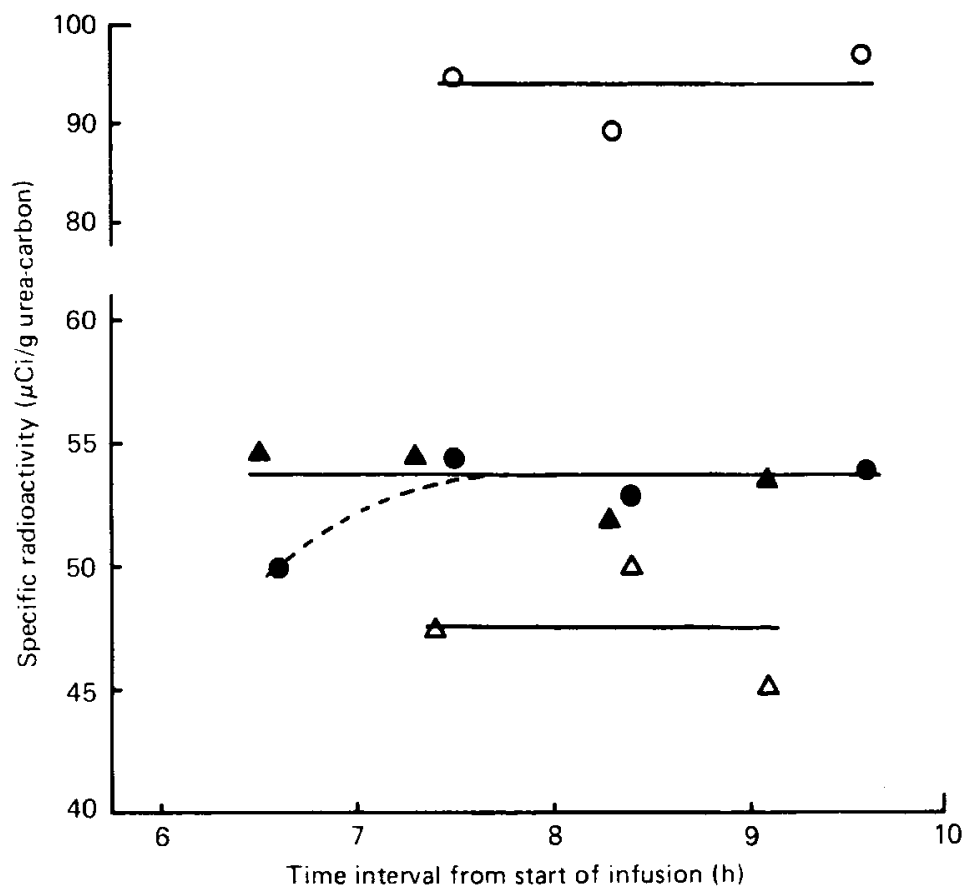

Fig. 2. Specific radioactivities of foetal $(O)$ and maternal $(O)$ plasma urea during a foetal infusion and of foetal $(\triangle)$ and maternal $(\Delta)$ plasma urea during a maternal infusion. The rate of infusion was $0 \cdot 30$ $\mu \mathrm{Ci} / \mathrm{min}$ to both foetus and mother (sheep F863).

less sure, the day 1 to day 2 concentration increase was small $(17 \pm 4 \%, n 10)$ and during the mathematical analysis the mean concentration for days 1 and 2 was used (see below). Plasma urea concentrations tended to be higher in the well-nourished animals (experimental series 1) and were consistently higher in the foetal than in the maternal samples from all animals (Table 1).

Plasma glucose concentrations (Table 1) are included to permit a comparison between the animals used in experimental series 1 and the animals used in previous studies of glucose kinetics (Hodgson et al. 1980, 1981). The mean ( \pm SEM) coefficient of within-day variation was $8 \cdot 8 \pm 2.2 \%(n 14)$ for foetal and $4 \cdot 4 \pm 0.5 \%(n 18)$ for maternal plasma glucose. Variations in plasma glucose concentrations between days were also small. Maternal and foetal plasma glucose concentrations were significantly $(P<0.001)$ higher in the wellnourished than in the undernourished sheep.

Plateau specific radioactivities of plasma urea were present at the time of first sampling in experimental series 1 (primed infusion) but when no priming dose was used (experimental series 2) plateau was reached after about $7 \mathrm{~h}$ of infusion (Fig. 2). The mean ( \pm SEM) plateau values are presented in Table 2 . The concentration of ${ }^{14} \mathrm{C}$ radioactivity (disintegrations/min per $\mathrm{ml}$ ) in deproteinized maternal plasma was the same, for a given rate of infusion, during maternal and foetal infusions in all animals. Thus the plateau specific radioactivities of maternal plasma urea calculated from the meaned urea concentrations (experimental series 1) or individual concentrations (experimental series 2) were independent of whether the mother or the foetus were infused.

Urea entry rates were calculated from the plateau specific radioactivity values and infusion rates (Table 3 ). The mean $( \pm \mathrm{SEM}$ ) maternal urea entry rate, expressed as $\mathrm{mg}$ of $\mathrm{urea} / \mathrm{min}$ per $\mathrm{kg}$ ewe live weight was $0.63 \pm 0.02$ in experimental series 1 and $0.50 \pm 0.03$ 
Table 2. Specific radioactivities (corrected for residual activity and to an infusion rate of $I$ $\mu \mathrm{Ci} / \mathrm{min}$ ) of foetal and maternal plasma urea

(Mean values with their standard errors)

\begin{tabular}{|c|c|c|c|c|c|c|c|c|c|c|}
\hline \multirow{3}{*}{$\begin{array}{l}\text { Experi- } \\
\text { mental } \\
\text { series }\end{array}$} & \multirow{3}{*}{$\begin{array}{c}\text { Nitrogen } \\
\text { intake } \\
(\mathrm{g} / \mathrm{d})\end{array}$} & \multirow[b]{3}{*}{ Sheep } & \multirow{3}{*}{$\begin{array}{l}\text { Foetal } \\
\text { age (d) }\end{array}$} & \multicolumn{6}{|c|}{$\begin{array}{l}\text { Plateau specific radioactivities } \\
(\mu \mathrm{Ci} / \mathrm{g} \text { of urea carbon) }\end{array}$} & \multirow{3}{*}{$\begin{array}{l}\text { Route of } \\
\text { foetal } \\
\text { infusion }\end{array}$} \\
\hline & & & & \multicolumn{2}{|c|}{$S R_{f}^{f}$} & \multicolumn{2}{|c|}{$\mathrm{SR}_{\boldsymbol{f}}^{\mathrm{m}}$} & \multicolumn{2}{|c|}{$\mathrm{SR}_{\mathrm{m}}^{+}$} & \\
\hline & & & & Mean & $\mathbf{S E}$ & Mean & $\mathrm{SE}$ & Mean & SE & \\
\hline \multirow[t]{5}{*}{1} & 33.8 & R345 & $131-132$ & $312^{*}$ & & 91 & 3 & 117 & 4 & UV \\
\hline & $29 \cdot 6$ & T681 & $125-126$ & 292 & 7 & 104 & 1 & 130 & 3 & UV \\
\hline & 38.0 & T849 & $126-127$ & $309^{*}$ & & 90 & 3 & 121 & 2 & UA \\
\hline & $38 \cdot 0$ & T849 & $133-134$ & $293^{*}$ & & 108 & 9 & 127 & 5 & UA \\
\hline & 38.0 & T849 & $140-141$ & 254 & 8 & $112^{*}$ & & $120^{*}$ & & $\mathbf{U A}$ \\
\hline \multirow[t]{4}{*}{2} & $10 \cdot 6$ & F839 & $140-141$ & $298^{*}$ & & $198^{*}$ & & 228 & 13 & UA \\
\hline & $12 \cdot 7$ & F842 & $138-139$ & $389^{*}$ & & 178 & 6 & 229 & 6 & UV \\
\hline & $10 \cdot 6$ & F851 & $141-142$ & $225^{*}$ & & 142 & 6 & 164 & 3 & UV \\
\hline & 16.9 & F863 & $142-143$ & 285 & 8 & $156^{*}$ & & 182 & 3 & UV \\
\hline
\end{tabular}

$\mathbf{S R}_{\mathrm{f}}^{\mathrm{p}}$, specific radioactivity in foetal circulation when infused into foetal circulation; $\mathbf{S R}_{\mathbf{f}}^{\mathrm{m}}$, specific radioactivity in foetal circulation when infused into maternal circulation; $\mathbf{S R}_{\mathrm{m}}$, specific radioactivity in maternal circulation when infused into either foetal or maternal circulation. UV, umbilical vein; UA, umbilical artery.

* These values are from the analysis of 8 and $9 \mathrm{~h}$ samples only.

$\dagger$ The maternal specific radioactivity values were the same, within the limits of experimental error, whether it was the mother or foetus infused.

Table 3. Foetal and maternal rates of entry of urea

\begin{tabular}{|c|c|c|c|c|c|}
\hline \multirow{2}{*}{$\begin{array}{l}\text { Experimental } \\
\text { series }\end{array}$} & \multirow{2}{*}{$\begin{array}{c}\text { Nitrogen } \\
\text { intake } \\
(\mathrm{g} / \mathrm{d})\end{array}$} & \multirow[b]{2}{*}{ Sheep } & \multirow{2}{*}{$\begin{array}{l}\text { Foetal } \\
\text { age (d) }\end{array}$} & \multicolumn{2}{|c|}{$\begin{array}{l}\text { Urea entry rates } \\
(\mathrm{mg} / \mathrm{min} \text { per } \mathrm{kg})\end{array}$} \\
\hline & & & & Foetal & Maternal \\
\hline \multirow[t]{5}{*}{1} & 33.8 & R345 & $131-132$ & $4 \cdot 61$ & 0.70 \\
\hline & $29 \cdot 6$ & T681 & $125-126$ & $6 \cdot 13$ & 0.66 \\
\hline & 38.0 & T849 & $126-127$ & 5.93 & 0.63 \\
\hline & 38.0 & T849 & $133-134$ & 4.99 & 0.57 \\
\hline & $38 \cdot 0$ & T849 & $140-141$ & $4 \cdot 70$ & 0.60 \\
\hline \multirow[t]{4}{*}{2} & $10 \cdot 6$ & F839 & $140-141$ & $4 \cdot 49$ & 0.49 \\
\hline & $12 \cdot 7$ & F842 & $138-139$ & 3.74 & 0.42 \\
\hline & $10 \cdot 6$ & F851 & $141-142$ & $5 \cdot 31$ & 0.57 \\
\hline & 16.9 & F863 & $142-143$ & 4.04 & 0.52 \\
\hline
\end{tabular}

in experimental series 2 . Foetal entry rates were approximately 8.5 times higher, with values for experimental series 1 and 2 of $5 \cdot 3 \pm 0 \cdot 3$ and $4 \cdot 4 \pm 0 \cdot 3 \mathrm{mg} / \mathrm{min}$ per $\mathrm{kg}$ foetus respectively.

\section{Urea fluxes within and between mother and foetus}

The rates of production in mother and foetus, maternal disposal and transplacental transfer of urea are given in Table 4 . The mean ( \pm SEM) rate of foetal urea production $\left(F_{\mathrm{fo}}\right)$, expressed as $\mathrm{mg}$ urea/min per $\mathrm{kg}$ foetus, was $1.45 \pm 0.28$ in experimental series 1 and $1.63 \pm 0 \cdot 14$ in experimental series 2 . In experimental series 1 there were no significant differences in the rate of foetal urea production between monotocous and ditocous ewes at similar gestational ages but repeat observations made in one ditocous ewe showed a progressive decline in the rate with gestational age. The mean $( \pm \mathrm{SEM})$ rates of maternal urea production $\left(F_{\mathrm{mo}}\right)$ and 


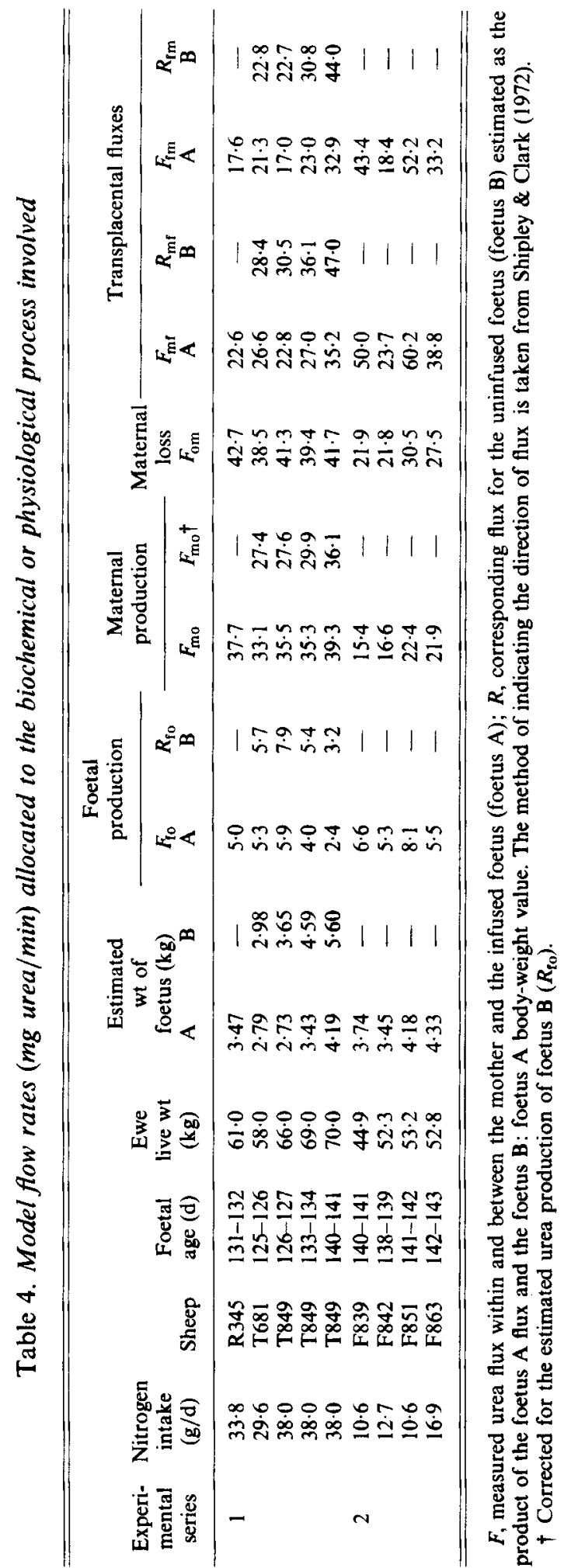


disposal $\left(F_{\mathrm{om}}\right)$, expressed as $\mathrm{mg}$ urea/min per $\mathrm{kg}$ ewe live weight, were $0.49 \pm 0.04$ and $0.63 \pm 0.02$ in experimental series 1 respectively and $0.37 \pm 0.03$ and $0.50 \pm 0.03$ in experimental series 2 respectively.

In both experimental series, the rates of transfer of urea between mother and foetus $\left(F_{\mathrm{mp}}\right.$ and $F_{\mathrm{fm}}$ ) were high (Table 4 ), accounting for 0.42 and 0.82 (experimental series 1 ) and 0.68 and 0.84 (experimental series 2 ) of the total entry of urea into the maternal and foetal pools respectively. The net urea flux was from the foetus to the mother and because of the model configuration was equivalent to the rate of foetal urea production. This net transfer followed the urea concentration gradient observed between maternal and foetal plasma.

For all animals there was a positive relationship between the maternal rate of urea disposal $\left(F_{\mathrm{om}} ; Y, \mathrm{mg}\right.$ urea/min $)$ and the dietary nitrogen intake $(X, \mathrm{~g} /$ day $)$ such that $Y=17.7+0.64 X(r 0.93 ; P<0.001)$.

\section{DISCUSSION}

The mean rate of net transfer of urea from the foetus to the mother in well-nourished sheep of $1.45 \mathrm{mg} / \mathrm{min}$ per $\mathrm{kg}$ foetus may be compared to the value of $1.33 \mathrm{mg} / \mathrm{min}$ per $\mathrm{kg}$ foetus $(n 4)$ obtained by other workers using a similar technique (Faichney \& White, 1980). These rates are higher than estimates of the transplacental excretion rate of urea in fed sheep $(0 \cdot 54$, $n 8$, Gresham et al. (1972); approximately $1, n 8$, Simmons et al. (1974); 0.4, $n 11$, Schreiner et al. (1978) $\mathrm{mg} / \mathrm{min}$ per $\mathrm{kg}$ foetus), obtained as the product of the placental urea clearance and the maternal-foetal arterial urea concentration difference. However, the estimate of the urea clearance obtained by Gresham et al. (1972) and used by the previously mentioned workers, required the system to be in an isotopic steady-state and the transplacental diffusion rate to be approximately equal to the infusion rate (see Meschia et al. 1967). A plot of plasma $\left[{ }^{14} \mathrm{C}\right]$ urea concentration $v$. time (Gresham et al. 1972) shows that their observational period of $4 \mathrm{~h}$ was not sufficient to establish isotopic equilibrium and if the $\left[{ }^{14} \mathrm{C}\right]$ urea concentration at $4 \mathrm{~h}$ is used to calculate the foetal urea entry rate, a value of approximately $10 \mathrm{mg} / \mathrm{min}$ per $\mathrm{kg}$ foetus is obtained, which is double the values reported in the present paper (Table 3). Also, when all the results from their study (Gresham et al. 1972; James et al. 1972) are combined, it can be estimated that the transplacental diffusion rate of $\left[{ }^{14} \mathrm{C}\right]$ urea was only approximately 0.5 of the infusion rate (cf. 0.95 for antipyrene, Meschia et al. 1967). The large fraction of infused $\left[{ }^{14} \mathrm{C}\right]$ urea still equilibrating with foetal fluids would necessarily mean that the placental urea excretion was seriously underestimated.

In the present work the tendency for the two-way transfer of urea across the placenta to be higher in undernourished compared with well-nourished animals (Table 4) was interesting, particularly as the placental transfer rates were also high at $140-141 \mathrm{~d}$ of gestation in the ewe with twins (T849). These high rates of urea transfer may therefore be a characteristic of this gestational age. Alternatively they may reflect an increased placental permeability at a time when the transfer of nutrients fails to meet foetal demands because of poor maternal nutrition or the extra requirements of twin foetuses near term.

\section{Foetal urea production rates and the availability of amino acids in well-nourished sheep}

It is known that the liver of the foetal sheep can synthesize urea (Rattenbury et al. 1980) and the maternal supply of amino acids to the foetus in fed animals appears sufficient to sustain the high rate of in vivo foetal urea production in addition to meeting the demands for foetal tissue synthesis. The rate of amino acid-N uptake by the foetus is about $1.5 \mathrm{~g} / \mathrm{d}$ per $\mathrm{kg}$ foetus (Lemons et al. 1976; Holtzman et al. 1979) and of this about $0.65 \mathrm{~g} / \mathrm{d}$ per $\mathrm{kg}$ foetus is required for net tissue synthesis (Battaglia \& Meschia, 1973; Lemons et al. 1976). Thus the rate of foetal urea production calculated in the present work, equivalent to 
$1.03 \mathrm{~g} \mathrm{~N} / \mathrm{d}$ per $\mathrm{kg}$ foetus, is not unrealistic given the amount of excess amino acid- $\mathrm{N}$ available.

\section{Interpretation of the foetal urea production rates in well-nourished sheep in terms of maximum rates of gluconeogenesis}

The maximum possible rates of foetal gluconeogenesis from amino acids estimated from the observed urea production rates were (mean \pm SEM) $2.28 \pm 0.44$ and $2.56 \pm 0.23 \mathrm{mg} / \mathrm{min}$ per $\mathrm{kg}$ foetus in well- and undernourished sheep respectively. The calculations were the same as those Nolan \& Leng (1970) applied to results from adult sheep, but the associated errors (see Bruckental et al. 1980) were much reduced in foetal estimates for two main reasons. First, unlike the mother, the foetus has only small amounts of ammonia to neutralize. Approximately $0.04 \mathrm{~g} \mathrm{~N} / \mathrm{d}$ per $\mathrm{kg}$ foetus enters foetal blood as ammonia via the placenta (Holzman et al. 1977) and would account for only 0.04 of the mean foetal urea production rate. Secondly, the proportion of deaminated amino acids which pass through the glucose pool may be much higher in the foetus than in the mother. Hodgson et al. (1980) calculated that the contribution of alanine- $C$ to foetal glucose synthesis (see Prior \& Christenson, 1977) might require 0.5 of the alanine- $C$ uptake from the mother, or all alanine- $C$ which was in excess of the requirement for tissue synthesis.

In the two well-nourished ditocous sheep the rate of foetal urea production indicated that foetal gluconeogenesis from amino acids could account for $0.4-0.5$ of the total rate of gluconeogenesis (cf. Hodgson et al. 1981), and the corresponding value in the one monotocous well-nourished ewe was 0.94 (cf. Hodgson et al. 1980). The lower possible contribution of amino acid-C to foetal gluconeogenesis in ditocous than in monotocous ewes is surprising in view of the higher observed rates of foetal gluconeogenesis in ditocous ewes (see Hodgson et al. 1981). It may be that some aspects of metabolism in well-nourished ditocous ewes resemble those in undernourished monotocous ewes (see p. 000) in which lactate contributes significantly to foetal glucose synthesis (Prior, 1980).

The progressive decline in the rate of foetal gluconeogenesis with gestational age which has been observed in well-nourished ditocous sheep (Hodgson et al. 1981) was matched in the present work by a progressive decline in the rate of foetal urea production in the ditocous ewe T849 (Table 4). This constitutes further circumstantial evidence of a link between foetal gluconeogenesis and urea production.

\section{Foetal urea production rates in undernourished animals}

A high rate of foetal urea production was also observed during undernutrition despite a probable reduction in the supply of amino acids from the mother. If a high production rate was maintained through catabolism of amino acids intended for foetal tissue synthesis it could in part explain the dramatic fall in the foetal growth rate which is known to occur during undernourishment of the type imposed here (Mellor \& Matheson, 1979; Mellor \& Murray, 1981, 1982).

\section{Interpretation of urea entry rates in pregnant and foetal sheep}

The mean rates of urea entry in the mother were 0.63 and $0.50 \mathrm{mg} / \mathrm{min}$ per kg ewe for mean dietary $\mathrm{N}$ intakes of 0.55 and $0.25 \mathrm{~g} / \mathrm{d}$ per $\mathrm{kg}$ ewe respectively. The values obtained by Nolan \& Leng (1970) in nine sheep were 0.56 and $0.39 \mathrm{mg} / \mathrm{min}$ per $\mathrm{kg}$ ewe for dietary $\mathrm{N}$ intakes of 0.52 and $0.12 \mathrm{~g} \mathrm{~N} / \mathrm{d}$ per $\mathrm{kg}$ ewe respectively. However, the present results indicate that caution is needed when interpreting urea entry rates in pregnant sheep when no correction is made for the foetal contribution to the maternal urea pool. Nolan \& Leng (1970) compared urea entry rates in monotocous and non-pregnant sheep at low dietary $\mathrm{N}$ intakes, and concluded that the higher maternal entry rate of urea found in pregnant sheep was 
indicative of a greater potential for maternal glucose synthesis from amino acids. A comparison of Tables 3 and 4 of the present work shows that on average the maternal rate of urea production $\left(F_{\text {mo }}\right)$ in undernourished monotocous sheep was 0.75 of the maternal entry rate. If this correction is applied to the results of Nolan \& Leng (1970) the distinction between the rates of urea production in undernourished monotocous and non-pregnant sheep is lost. A comparison of the foetal results in Tables 3 and 4 shows that on average the true rate of foetal urea production $\left(F_{\mathrm{fo}}\right)$ is only 0.31 of the foetal urea entry rate.

The authors thank all who assisted in this work and in particular Mr A. Anderson, Mr D. P. Knox, Miss A. McBean, Mr L. Murray and Miss A. J. Peggram.

\section{REFERENCES}

Battaglia, F. C. \& Meschia, G. (1973). In Barcroft's Centenary Symposium on Foetal and Neonatal Physiology, p. 382. London: Cambridge University Press.

Bruckental, 1., Oldham, J. D. \& Sutton, J. D. (1980). Br. J. Nutr. 44, 33.

Faichney, G. J. \& White, G. A. (1980). Proc. Nutr. Soc. Aust. 5, 211 .

Fawcett, J. K. \& Scott, J. E. (1960). J. clin. Path. 13, 156.

Gresham, E. L., James, E. J., Raye, J. R., Battaglia, F. C., Makowski, E. L. \& Meschia, G. (1972). Pediatrics, Springfield 50, 372.

Hodgson, J. C. \& Mellor, D. J. (1977). Proc. Nutr. Soc. 36, 33.

Hodgson, J. C., Mellor, D. J. \& Field, A. C. (1980). Biochem. J. $186,739$.

Hodgson, J. C., Mellor, D. J. \& Field, A. C. (1981). Biochem. J. 196, 179.

Holzman, I. R., Lemons, J. A., Meschia, G. \& Battaglia, F. C. (1977). Proc. Soc. exp. Biol. Med. 156, 27.

Holzman, I. R., Lemons, J. A., Meshia, G. \& Battaglia, F. C. (1979). J. devel. Physiol. 1, 137.

James, E. J., Raye, J. R., Gresham, E. L., Makowski, E. L., Meschia, G. \& Battaglia, F. C. (1972). Pediatrics, Springfield 50, 361.

Lemons, J. A., Adcock III, E. W., Jones Jr., M. D., Naughton, M. A., Meschia, G. \& Battaglia, F. C. (1976). J. clin. Invest. $\mathbf{5 8}, 1428$.

Lindsay, D. B. (1978). Biochem. Soc. Trans. 6, 1152.

Mellor, D. J. \& Matheson, I. C. (1979). Q. Jl exp. Physiol. 64, 119.

Mellor, D. J. \& Murray, L. (1981). Res. vet. Sci. 30, 198.

Mellor, D. J. \& Murray, L. (1982). Res. vet. Sci. (In the Press).

Meschia, G., Battaglia, F. C. \& Bruns, P. D. (1967). J. appl. Physiol. 22, 1171.

Nolan, J. V. \& Leng, R. A. (1970). Br. J. Nutr. 24, 905.

Prior, R. L. (1980). Am. J. Physiol. 239, E208.

Prior, R. L. \& Christenson, R. K. (1977). Am. J. Physiol. 233, E462.

Rattenbury, J. M., Jeacock, M. K. \& Shepherd, D. A. L. (1980). Biochim. biophys. Acta 630, 210.

Schreiner, R. L., Burd, L. I., Jones Jr., M. D., Lemons, J. A., Sheldon, R. E., Simmons, M. A., Battaglia, F. C. \& Meschia, G. (1978). In Fetal and Newborn Cardiovascular Physiology, vol, 2, p. 197 [L. G. Longo and D. D. Reneau, editors]. New York and London: Garland STPM Press.

Shipley, R. A. \& Clark, R. E. (1972). Tracer Methods for In Vivo Kinetics: Theory and Applications. New York and London: Academic Press.

Simmons, M. A., Meschia, G., Makowski, E. L. \& Battaglia, F. C. (1974). Pediat. Res. 8, 830.

Somogyi, M. (1945). J. biol. Chem. 160, 69.

Trinder, P. (1969). Ann. clin. Biochem. 6, 24.

Wainman, F. W., Blaxter, K. L. \& Pullar, J. D. (1970). J. agric. Sci.. Camb. 74, 311. 